\title{
Quantification of direct and indirect greenhouse gas emissions from rice field cultivation with different rice straw management practices - A study in the autumn - winter season in An Giang Province, Vietnam
}

\author{
Phát thải khí nhà kính trực tiếp và gián tiếp từ sản xuất lúa theo các biện pháp quản lý rơm rạ \\ khác nhau - Một nghiên cứu ở vụ Thu Đông ở tỉnh An Giang, Việt Nam
}

\author{
NGO Thi Thanh Truc ${ }^{*}$; HO Vu Khanh ${ }^{2}$; TRAN Sy Nam ${ }^{3}$; DUONG Van Chin ${ }^{4}$; NGUYEN Van \\ Cong $^{3}$; NGUYEN Van Hung ${ }^{5}$
}

${ }^{1}$ Department Environmental and Resource Economics, College of Economics, Can Tho University, Can Tho, Vietnam; ${ }^{2}$ Faculty of Environment and Natural Resources, Kien Giang University, Kien Giang Province, Vietnam; ${ }^{3}$ Department of Environmental Science, College of Environment and Natural Resources, Can Tho University, Can Tho, Vietnam; ${ }^{4}$ Loc Troi Group, An Giang Province, Vietnam; International Rice Research Institute, Los Baños, Philippines

\begin{abstract}
This study resulted in a comparative analysis of greenhouse gas emissions (GHGE) for rice production with different infield rice straw management practices based on an experiment conducted in An Giang Province of Vietnam, during the autumn - winter season of 2016. Direct field GHGE was analyzed based on in-situ measurement and the total direct and indirect GHGE were estimated by applying the life cycle assessment using Ecoinvent3 database which is incorporated in SIMAPRO software. The experiment was conducted based on a completely random design with three treatments and three replications. The three treatments are [T1] Incorporation of straw and stubbles treated with Trichoderma; [T2] Incorporation of stubbles and removal of straw; and [T3] In-field burning straw. Closed chamber protocol and gas chromatography (SRI 8610C) was used to measure and analyse $\mathrm{CH}_{4}$ and $\mathrm{N}_{2} \mathrm{O}$. $\mathrm{CH}_{4}$ emission rate was not significantly different ( $p>0.05$ ) among the three treatments during sampling dates except on the days 17 and 24 after sowing (DAS). $\mathrm{N}_{2} \mathrm{O}$ emission rate was not significantly different ( $p>0.05$ ) either. However, there were high variations of $\mathrm{N}_{2} \mathrm{O}$ emission after the dates of urea applied. Direct field emissions of $\mathrm{CH}_{4}, \mathrm{~N}_{2} \mathrm{O}$ and $\mathrm{CO} 2$ equivalent $\left(\mathrm{CO}_{2 \text { eq }}\right)$ are not significantly different among the three treatments, but the amount of $\mathrm{CO} 2$ eq per kg straw in $\mathrm{T} 1$ of incorporating rice straw treated with Trichoderma is significantly higher than in T3 of in-field burning straw. LCA based analysis resulted in total GHGE in the range of 1.93-2.46 $\mathrm{kg} \mathrm{CO}_{2}$-eq $\mathrm{kg}^{-1}$ paddy produced consisting of 53-66\% from direct soil emissions. Incorporation of straw treated with Trichoderma did not indicate the improvement of paddy yield. However, the organic matter, $\mathrm{N}-\mathrm{NH}_{4}{ }^{+}$, and $\mathrm{N}-\mathrm{NO}_{3}{ }^{-}$of this treatment was higher than those of the other researched treatments. This research was just conducted in one crop season, however, the results have initial implications for the other crop seasons.
\end{abstract}

\begin{abstract}
Nghiên cứu này phân tích phát thải khí nhà kính từ sản xuất lúa theo các biện pháp quản lý rơm rạ khác nhau dựa vào thí nghiệm được thực hiện ở vụ Thu Đông năm 2016 tại tỉnh An Giang, Việt Nam. Lượng phát thải khí nhà kính từ đất đã được phân tích dựa vào kết quả đo đạt tại ruộng và tổng lượng phát thải khí nhà kính trực tiếp và gián tiếp được ước tính bằng phương pháp vòng đời sử dụng cơ sở dữ liệu Ecoinvent3 gắn kết với phần mềm SIMAPRO. Thí nghiệm được bố trí hoàn toàn ngẫu nhiên gồm 3 nghiệm thức và 3 lần lặp lại. Các nghiệm thức gồm [T1] vùi rơm và rạ với Trichoderma, [T2] lấy rơm ra khỏi ruộng và vùi rạ và [T3] đốt rơm. Kỹ thuật buồng kín (closed chamber protocol) và máy sắc ký khí (SRI8610C) được sử dụng để đo đạt và phân tích khi $\mathrm{CH}_{4}$ và $\mathrm{N}_{2} \mathrm{O}$. Tốc độ phát thải khí $\mathrm{CH}_{4}$ không khác biệt giữa ba nghiệm thức, ngoại trừ kết quả ở lần lấy mẫu 17 và 24 ngày sau sạ. Tốc độ phát thải $\mathrm{N}_{2} \mathrm{O}$ cũng không có sự khác biệt giữa các nghiệm thức. Tuy nhiên, tốc độ phát thải biến động rất lớn sau các ngày bón phân đạm. Lượng phát thải trực tiếp từ ruộng của $\mathrm{CH}_{4}, \mathrm{~N}_{2} \mathrm{O}$ và $\mathrm{CO}_{2}$ tương đương $\left(\mathrm{CO}_{2}\right.$-eq) không có sự khác biệt giữa ba nghiệm thức, nhưng lượng $\mathrm{CO}_{2}-e q / \mathrm{kg}$ rơm ở nghiệm thức vùi rơm và rạ với Trichoderma (T1) cao hơn nghiệm thức đốt rơm (T3). Kết quả phân tích LCA cho thấy lượng phát thải khi nhà kính dao động trong khoảng 1,93-2,46 kg CO -eq/kg lúa với 53 - 66\% lượng phát thải trực tiếp từ trong đất. Vùi rơm rạ với Trichoderma chưa cải thiện được năng suất lúa. Tuy nhiên, phần trăm chất hữu cơ và hàm lượng đạm hữu dụng trong đất của nghiệm thức này cao hơn so với hai nghiệm thức còn lại của thí nghiệm. Nghiên cứu này chỉ mới được thực hiện một vụ, nhưng đã mang lại nhiều kết quả có thể ứng dụng cho các vu sau.
\end{abstract}

Keywords: GHGE, methane, nitrous oxide, straw management practices 


\section{Introduction}

Lowland rice cultivation is one of the important sources of greenhouse gas emissions in agriculture (Bhattacharyya et al., 2012). According to VSC (2014), Vietnam emitted approximately 46 thousand tons of $\mathrm{CO}_{2 \text { eq }}$ from rice production, which accounted for $50.5 \%$ of total GHGE from agricultural activities. Causes of greenhouse gas emissions in rice production are irrigated rice cultivation, over-fertilization, unsustainable straw and water management, and high density of sowing (Wassmann, 2000; Trinh et al., 2013; Tin et al., 2015).

Mekong Delta produces about 24 - 26 million tons of rice straw annually (GSO, 2016; Arai et al., 2015). However, the most common practice of rice straw management is open burning (54 - 98\%) and incorporating fresh rice straw (7 26\%) (Nam et al., 2014; Truc et al., 2012). Only $2-13 \%$ of rice straw is used to produce straw mushroom (Volvariella vovaraceae) and feed for cattle. Burning rice straw is popular due to intensification, limit of straw utilization, and lack of regulation on burning straw (Truc et al., 2012 and 2013).

Open burning rice straw causes air pollution and loss of nutrients while incorporating fresh straw and stubble releases greenhouse gas emissions, as well as organic poison to the young paddy (Gadde et al., 2009; Gao et al., 2003; Nguyen Quoc Khang and Ngo Ngoc Hung, 2014). In order to recommend the better practice of rice straw management, an experiment on in-situ rice straw practice has been conducted to estimate direct and indirect greenhouse gas emissions. The first treatment was incorporating rice straw and stubble with Trichoderma. Trichoderma acts as an activator to speed up the decomposition process in $15-25$ days, reducing organic poison when incorporated with fresh straw or stubble to the paddy field; and supplementing organic nutrients as well (Son et al., 2008; Tuyen and Tan, 2001). The two other treatments are incorporating fresh stubble directly to the field, and in-field burning of rice straw which is the most practiced rice straw management in the Mekong Delta (Nam et al., 2014). After quantifying in-situ greenhouse gas emission, this study also calculated the total greenhouse gas emission by life cycle assessment.

\section{Materials and methodologies}

\subsection{Experiment set up and materials}

Materials: Rice cultivation was conducted during AutumnWinter seasons of 2016 (August to December) at Dinh Thanh Agricultural Research Center in An Giang province of $\mathrm{Vi}$ etnam ( $\left.10^{\circ} 18^{\prime} 45.19^{\prime \prime} \mathrm{N} ; 105^{\circ} 18^{\prime} 57.87^{\prime \prime} \mathrm{E}\right)$. The experimental design applied was the Complete Randomized Design (CRD) with 3 treatments namely [T1] Incorporation of straw and stubbles treated with Trichoderma; [T2] Incorporation of stubbles and removal of straw; and [T3] In-field burning straw. The experimental plot of $25 \mathrm{~m}^{2}$ and three replications were done. The quantity of straw and stubble added in the experiment is listed in Table 1.

\begin{tabular}{|c|c|c|c|}
\hline \multirow[t]{2}{*}{ Treatment } & \multirow{2}{*}{$\begin{array}{c}\text { Straw } \\
\text { management }\end{array}$} & \multicolumn{2}{|c|}{ Quantity $\left(\mathrm{kg} \mathrm{ha}^{-1}\right)$} \\
\hline & & Straw & Stubble \\
\hline$\overline{\mathrm{T} 1}$ & Incorporated & $2,697 \pm 140^{a}$ & $3,852 \pm 201^{a}$ \\
\hline $\mathrm{T} 2$ & Removed & $2,563 \pm 7.1^{a}$ & $3,660 \pm 10.1^{a}$ \\
\hline T3 & Burning & $2,850 \pm 86.6^{a}$ & $4,071 \pm 124^{a}$ \\
\hline
\end{tabular}

Note: Means followed by the same letter are not significantly different among sampling days at 0.05 level as determined by Duncan

Agronomic and chemical inputs for the three treatments are described in Table 2. Rice seeds were sown by drum seeder. Fertilizer was applied at 10, 20, and 50 days after sowing (DAS) (panicle initiation stage).

Table 2. Agronomic and chemical inputs in the experiment Unit: $k g \mathrm{ha}^{-1}$

\begin{tabular}{llr} 
Inputs & Trade name & Quantity \\
\hline Variety & Loc Troi 1 & 100 \\
Trichoderma & TRICO-DHCT-LUA VON & $1^{*}$ \\
$\mathrm{~N}$ & Urea $(46 \% \mathrm{~N}) ;$ DAP & 90 \\
& $\left(18 \% \mathrm{~N}-46 \% \mathrm{P}_{2} \mathrm{O}_{5}\right)$ & \\
$\mathrm{P}_{2} \mathrm{O}_{5}$ & DAP $\left(18 \% \mathrm{~N}-46 \% \mathrm{P}_{2} \mathrm{O}_{5}\right)$ & 45 \\
$\mathrm{~K}_{2} \mathrm{O}$ & $\mathrm{KCl}\left(46 \% \mathrm{~K}_{2} \mathrm{O}\right)$ & 45
\end{tabular}

Note: only Trichoderma was added in T1

\subsection{Measurement and analysis}

Gas measurement: Gas measurement and analysis were adopted from the guideline of Minamikawa et al., (2015). Gas samples were collected based on closed chamber method at 0, 10, 20, and 30 minutes, then stored in $30 \mathrm{ml}$ vacuum vials.
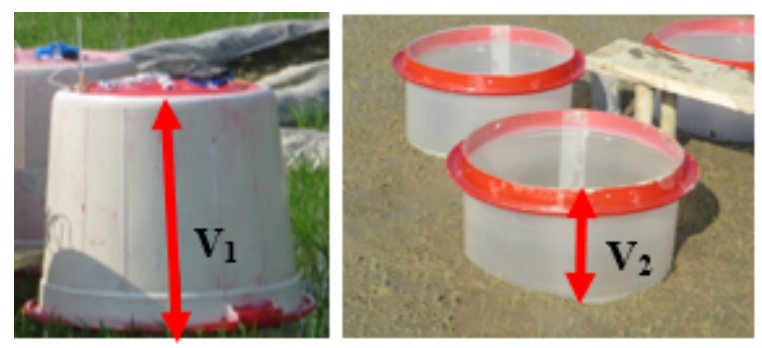

Figure 1. Chamber to collect a gas sample

The chamber contains two main parts namely, the gas chamber with a volume of $120 \mathrm{~L}$ and height $70 \mathrm{~cm}$ height $(\mathrm{V} 1)$, and the base with a diameter of $50 \mathrm{~cm}$ and height of $30 \mathrm{~cm}$ (V2) (Figure 1).

Samplings of GHGE were conducted after 10 DAS. The gas samples were collected at 9 am every week until 45 DAS and every ten days until 95 DAS. $\mathrm{CH}_{4}$ and $\mathrm{N}_{2} \mathrm{O}$ concentration were analysed using gas chromatography (Model SRI 8610C, Haye Sept-N) with FID and ECD detectors. 
Direct field-emission formula: $\mathrm{CH}_{4}$ and $\mathrm{N}_{2} \mathrm{O}$ rates were estimated by the following formula (Parkin et al., 2003):

$$
F=\frac{d C}{d t} x \frac{M V^{*} 60 * 24 * 10}{A^{*}\left(0.08206^{*} T\right)}
$$

where $\mathrm{F}: \mathrm{CH}_{4}$ or $\mathrm{N}_{2} \mathrm{O}$ flux (mg.m $\mathrm{m}^{-2}$.day $\left.{ }^{-1}\right)$; $\mathrm{T}$ : temperature in the chamber $\left({ }^{\circ} \mathrm{K}\right)$; $\mathrm{V}$ : volume of chamber; $\mathrm{M}$ : molecular weight of $\mathrm{CH}_{4}$ or $\mathrm{N}_{2} \mathrm{O}$; $\mathrm{A}$ : surface area of chamber $\left(\mathrm{m}^{2}\right)$; $\frac{d C}{d t}$ : rate of gas concentration in the chamber $\left(\mathrm{ppm} \cdot \mathrm{h}^{-1}\right)$; and $\mathrm{V}$ : volume of chamber $\left(\mathrm{V}=\mathrm{V}_{1}+\mathrm{V}_{2}\right)$. Again, $\mathrm{V}_{1}$ is the upper part of the chamber, $\mathrm{V} 2$ is the lower part of the cham$\operatorname{ber}\left(V_{2}=A\right.$.h); while $h$ is the height of water level from the ground surface inside the chamber and adjusted when the water level is higher than the ground surface.

The average emission rate is calculated by:

$$
\bar{F}=\frac{\sum_{1}^{n} F_{i}}{n}
$$

where $\mathrm{F}_{\mathrm{i}}: \mathrm{CH}_{4}$ or $\mathrm{N}_{2} \mathrm{O}$ flux of sampling date $\left(\mathrm{mg} \cdot \mathrm{m}^{-2}\right.$.day ${ }^{-1}$ ), and $n$ : number of gas sampling $(n=11)$. The total quantity of $\mathrm{CH}_{4}$ or $\mathrm{N}_{2} \mathrm{O}$ emission per season (autumn-winter season) is equal to $\bar{F}$ multiply by the number of days per season (100 days).

Indirect field-emission formula: GHGE conversion factors of all related materials were based on the database of Ecoinvent3 incorporated in SIMAPRO software. Diesel consumption for mechanized operations and seed rate were assumed 150 litres and $100 \mathrm{~kg}$ per ha based on the normal practices observed in the experimented areas.

Indirectly calculated emissions of the fuel consumptions and agronomic inputs used the conversion factors shown in Table 3.

For straw burning, we used the emission factors of $\mathrm{CH}_{4}$ and $\mathrm{N}_{2} \mathrm{O}$ reported in Romasanta et al. (2017). This indicated that burning 1 ton of straw (dry matter) caused the emissions of 4.5 and 0.069 gram of $\mathrm{CH}_{4}$ and $\mathrm{N}_{2} \mathrm{O}$, respectively.

Table 3. GHGE conversion factors of fuel, agronomic inputs,

\begin{tabular}{|c|c|c|c|}
\hline \multirow[t]{2}{*}{ Parameters } & \multicolumn{2}{|c|}{ GHGE } & \multirow[t]{2}{*}{ Source } \\
\hline & Unit & Value & \\
\hline Seeds & $\mathrm{kgCO}_{2}$-eq kg ${ }^{-1}$ & 1.12 & $\mathrm{a}$ \\
\hline Diesel consumption & $\mathrm{kgCO}_{2}$-eq $\mathrm{MJ}^{-1}$ & 0.08 & $a$ \\
\hline Nitrogen (N) & $\mathrm{kgCO}_{2}$-eq $\mathrm{kg}^{-1}$ & 5.68 & a \\
\hline $\mathrm{P}_{2} \mathrm{O}_{5}$ & $\mathrm{kgCO}_{2}$-eq kg ${ }^{-1}$ & 1.09 & a \\
\hline $\mathrm{K}_{2} \mathrm{O}$ & $\mathrm{kgCO}_{2}$-eq kg ${ }^{-1}$ & 0.52 & $\mathrm{a}$ \\
\hline $\mathrm{CH}_{4}$ & $\mathrm{kgCO}_{2}$-eq kg ${ }^{-1}$ & 30.5 & $b$ \\
\hline $\mathrm{N}_{2} \mathrm{O}$ & $\mathrm{kgCO}_{2}$-eq kg ${ }^{-1}$ & 265 & $b$ \\
\hline
\end{tabular}
and products

\section{Soil and water measurements}

Soil samples were collected before incorporating straw and stubbles, 30, 60 and 90 DAS for each plot. Soil samples were taken at $0-20 \mathrm{~cm}$ from the surface to measure $\mathrm{N}$ $\mathrm{NH}_{4}^{+} / \mathrm{N}-\mathrm{NO}_{3}{ }^{-}$and organic content.

Redox was measured in all nine plots with three replications by SWC-201RP at the same date and time of gas sample collection (at 9 am on the gas sampling date).

Water management followed the alternate wetting and drying (AWD) technology. However, it was not followed strictly due to the rainy season. The water level was recorded at 8 am every day at the experiment plot.

Crop measurement: Actual paddy yield was estimated by harvesting yield of $5 \mathrm{~m}^{2}$ plots in all nine treatment plots and estimated dry yield (at 14\% moisture content).

\subsection{Statistical analysis}

Means among treatments of $\mathrm{CH}_{4}, \mathrm{~N}_{2} \mathrm{O}$ and $\mathrm{CO}_{\text {-eq }}$ and related parameters were tested by analysis of variance with Duncan test of $95 \%$ confidence. Besides, correlation analysis of water level and redox was also used by Pearson tests.

\section{Results and discussions}

\subsection{Water level and redox potential}

Water levels in the paddy field varied from $-13 \mathrm{~cm}$ to $5 \mathrm{~cm}$ during experimental 95-day-period (Fig. 1a). Water management in this experiment tried to follow the alternate wetting and drying (AWD) technology even it was in rainy season. According to Bharati et al. (2001), the water level in the paddy field may affect the oxidation process in the soil, and thus may affect the emissions of $\mathrm{CH}_{4}$ and $\mathrm{N}_{2} \mathrm{O}$. However, there are no significant correlations between water level and redox among three treatments.

In the first 45 DAS, the redox potential was low ranging from -120 to $-160 \mathrm{mV}$ in all treatments (period of $10-46$ days in Fig. 2b). It is indicated that the reduction process in the soil was the main process which happened during this period. The reason for this trend was caused by the fast degradation of the straw biomass in the first 45 DAS. Then the redox increased gradually until 95 DAS due to the low water level and slow straw degradation at the end of the season. 

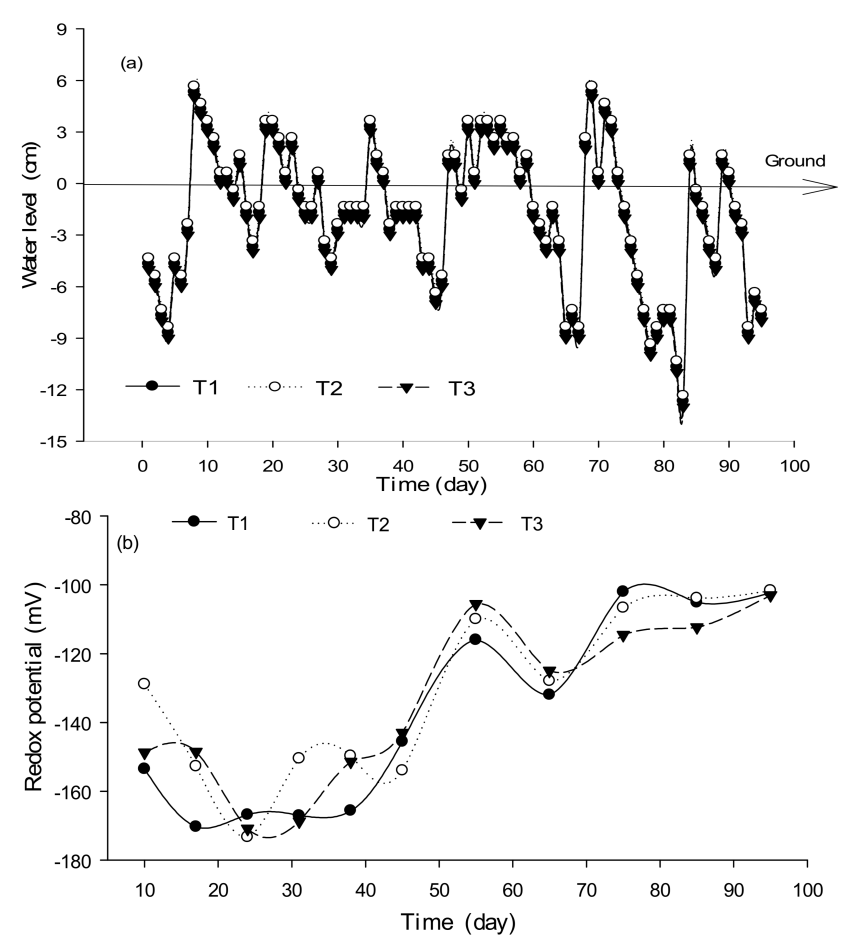

Figure 2. Water level (a) and redox potential (b)

\subsection{Emissions of $\mathrm{CH}_{4}$ and $\mathrm{N}_{2} \mathrm{O}$}

\subsubsection{Directly emission rate of $\mathrm{CH}_{4}$}

The average $\mathrm{CH}_{4}$ emission rates of $\mathrm{T} 1, \mathrm{~T} 2$ and $\mathrm{T} 3$ treatments fluctuated from $139.7-222.6 \mathrm{mg} \cdot \mathrm{m}^{-2}$. day ${ }^{-1}$ (Fig. 3). The emission rate of $\mathrm{CH}_{4}$ in $\mathrm{T} 1$ was not significantly different from $\mathrm{T} 2$ and $\mathrm{T} 3$ treatments ( $p>0.05)$ in most of the sampling dates, except in 17 and 24 DAS. The strong decomposition process of $\mathrm{T} 1$ during this period may be the reason for the high $\mathrm{CH}_{4}$ emission in comparison with $\mathrm{T} 2$ and T3. According to Du et al (2014), Trichoderma can decompose up to $40 \%$ of the straw within 20 days. Another report from Hoi (2008) concluded that the decomposition rate of rice straw was highest in the first 15 days, then the decomposition rate slows down causing the straw weight to decrease slowly.

There are high variations in $\mathrm{CH} 4$ emission rates among previous researches. For example, Neue and Sass (1998) reported that the average $\mathrm{CH}_{4}$ emission rate in a rice field ranged from 240 to $520 \mathrm{mg} \cdot \mathrm{m}^{-2}$ days $^{-1}$. Meanwhile, the study conducted by Bhattacharyya et al. (2012) showed that $\mathrm{CH}_{4}$ emission rates ranged from 45.6 - $137 \mathrm{mg} . \mathrm{m}$ ${ }^{2}$. days ${ }^{-1}$. The lowest emission rate was 85 DAS at 5.87 $\mathrm{mg} \cdot \mathrm{m}^{-2}$.days $\mathrm{s}^{-1}$ in which water level was $-1 \mathrm{~cm}$ and redox was $-112 \mathrm{mV}$ in all treatments (Fig 3).

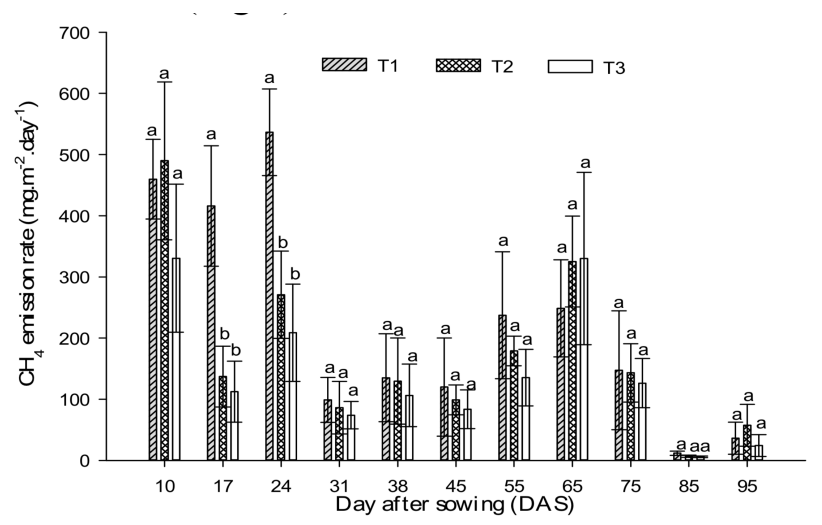

Figure 3. Direct emission rate of $\mathrm{CH}_{4}$

Note: Means followed by the same letter are not significantly different among sampling days at 0.05 level as determined by Duncan

\subsubsection{Directly emission rate of $\mathrm{N}_{2} \mathrm{O}$}

The emission of $\mathrm{N}_{2} \mathrm{O}$ in three treatments varied from 0 $6.57 \mathrm{mg} \cdot \mathrm{m}^{-2} \cdot \mathrm{day}^{-1}$ and there were no $\mathrm{N}_{2} \mathrm{O}$ emissions in most of the sampling dates (Fig. 4). The data showed that just after applying chemical fertilizers, the $\mathrm{N}_{2} \mathrm{O}$ emission was increased later. When fertilizers were applied on 8, 20, and 55 DAS, the $\mathrm{N}_{2} \mathrm{O}$ emissions on 10, 24, and 65 DAS were dramatically increased (Fig. 4). Snyder et al. (2007) also reported that $\mathrm{N}_{2} \mathrm{O}$ emissions are closely related to the amount of nitrogen applied in the field. However, there was no significant difference among the three treatments in terms of $\mathrm{N}_{2} \mathrm{O}$ emission $(p>0.05)$. It seemed that $\mathrm{N}_{2} \mathrm{O}$ emission is more closely related to fertilizer application than straw management practices.

The knowledge and research on $\mathrm{N}_{2} \mathrm{O}$ emission from the paddy field were quite limited compared to $\mathrm{CH}_{4}$ (Jiang et al., 2003). However, according to Lou et al., (2007), incorporating rice straw increases $\mathrm{N}_{2} \mathrm{O}$ emission, in comparison with removing the straw from the field. The emission of $\mathrm{N}_{2} \mathrm{O}$ is increased when the soil is fertilized by organic matter, due to the increased nitrate reduction and nitrification of $\mathrm{NH}_{4}{ }^{+}$in partly or full aerobic condition (Khuong and Hung, 2014).

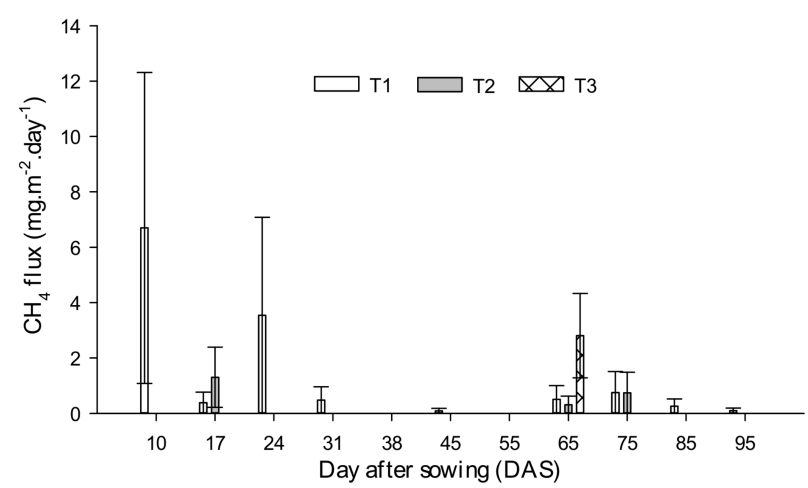

Figure 4. Direct emission rate of $\mathrm{N}_{2} \mathrm{O}$

\subsubsection{Total directly emission of $\mathrm{CH}_{4}, \mathrm{~N}_{2} \mathrm{O}$ and $\mathrm{CO}_{2 \text { eq }}$}

a. Total $\mathrm{CH}_{4}$ and $\mathrm{N}_{2} \mathrm{O}$ of direct emissions 
Fig. 5 illustrates that the average total emission of $\mathrm{CH}_{4}$ is $179.1 \pm 24.0 \mathrm{~kg} \cdot \mathrm{ha}^{-1}$. season $^{-1}$ (T1, T2 and T3 are 222.6, 174.9 , and $139.7 \mathrm{~kg} . \mathrm{ha}^{-1}$. season $^{-1}$, approximately). The statistical analysis showed that there was no significant difference in $\mathrm{CH}_{4}$ emissions among the three treatments $(p>0.05)$. This value is higher than the value reported by Linquist et al. (2012) at $100 \mathrm{~kg} \mathrm{CH}_{4} \cdot \mathrm{ha}^{-1}$. season $^{-1}$.

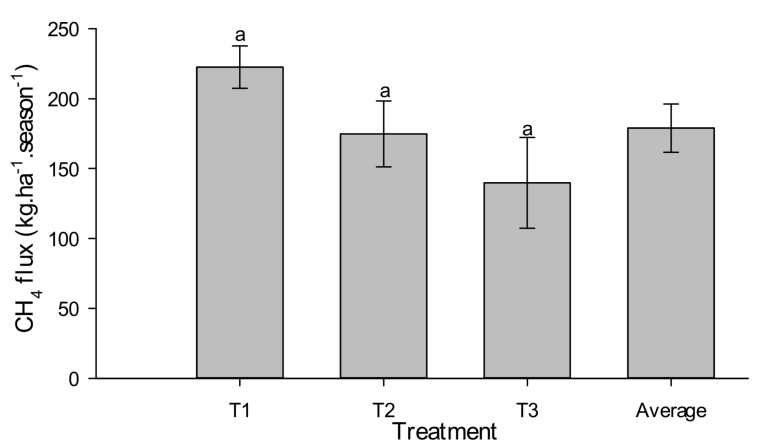

Figure 5. Total emission of $\mathrm{CH}_{4}$

Note: Means followed by the same letter are not significantly different at 0.05 level as determined by Duncan

Similarly, there was no significant difference in $\mathrm{N}_{2} \mathrm{O}$ emissions among three treatments, and it highly fluctuated

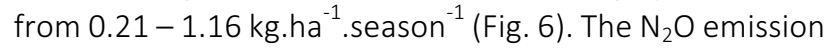
also varied in all treatments (Fig. 6). Studying paddy fields, Pittelkow et al. (2013) stated that the total emissions were 0.2 to $0.4 \mathrm{~kg} \mathrm{~N}_{2} \mathrm{O}$.ha ${ }^{-1}$, which was lower than the $\mathrm{N}_{2} \mathrm{O}$ emis- sion found in this study. The result of $\mathrm{N}_{2} \mathrm{O}$ needs to be confirmed by repeating this experiment in both dry and wet seasons.

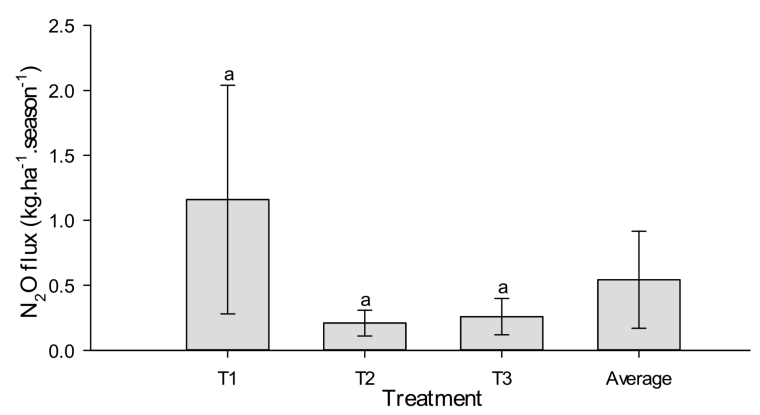

Figure 6. Total emission of $\mathrm{N}_{2} \mathrm{O}$

Note: Means followed by the same letter are not significantly different at 0.05 level as determined by Duncan

\section{b. Total direct emissions of $\mathrm{CO}_{2 e a}$}

The emission of $\mathrm{CO}_{2 \text { eq }}$ was 4,330 - 7,097 $\mathrm{kg} \mathrm{CO}$ 2eq. ha ${ }^{-1}$ and it was not significantly different among the three treatments (Table 4). However, the emission of $\mathrm{CO}_{2 \text { eq }}$ per $\mathrm{kg}$ of rice straw incorporated to the rice field with Trichoderma in T1 $\left(2.63 \pm 0.24 \mathrm{~kg} \mathrm{CO}\right.$ eq. $\mathrm{ha}^{-1}$. $\mathrm{kg}$ rice straw $\left.{ }^{-1}\right)$ was significantly higher than that of T3 treatment $(1.52 \pm 0.35 \mathrm{~kg}$ $\mathrm{CO}_{2 \text { eq. }} \cdot \mathrm{ha}^{-1} . \mathrm{kg}$ rice straw ${ }^{-1}$ ). The result of this study is in agreement with that reported in 2006 IPCC guidelines and other studies for the similar studies of straw incorporation with Trichoderma or compost (Truc, 2011; Wassmann et al, 2000).

\section{Table 4. $\mathrm{CO}_{2}$ equivalent emission}

\begin{tabular}{|c|c|c|c|c|c|}
\hline Treatment & $\begin{array}{l}\text { Yields } \\
\left(\mathrm{kg}^{\mathrm{h}} \mathrm{ha}^{-1}\right)\end{array}$ & $\begin{array}{l}\text { Rice straw } \\
\left(\mathrm{kg}_{\mathrm{ha}}{ }^{-1}\right)\end{array}$ & $\begin{array}{c}\mathrm{CO}_{2 \mathrm{eq}} \\
\left(\mathrm{kgCO}_{2} \cdot \mathrm{ha}^{-1} \cdot \text { season }^{-1}\right)\end{array}$ & $\begin{array}{c}\mathrm{CO}_{2 \mathrm{eq}} \\
\left(\mathrm{kgCO}_{2 \mathrm{eq}} . \mathrm{kg} \mathrm{paddy}^{-1} \text {. } \text { season }^{-1}\right)\end{array}$ & $\begin{array}{c}\mathrm{CO}_{2 \mathrm{eq}} \\
\left(\mathrm{kgCO}_{2} \cdot \mathrm{kg} \mathrm{straw}^{-1} \text {.season }\right.\end{array}$ \\
\hline T1 & $4,360 \pm 112^{a}$ & $2,697 \pm 140^{a}$ & $7,097 \pm 639^{a}$ & $1.62 \pm 0.15^{a}$ & $2.63 \pm 0.24^{a}$ \\
\hline $\mathrm{T} 2$ & $4,400 \pm 97.0^{a}$ & $2,563 \pm 7.10^{a}$ & $5,390 \pm 743^{a}$ & $1.22 \pm 0.17^{a}$ & $2,10 \pm 0.29^{a b}$ \\
\hline T3 & $4,250 \pm 85.0^{a}$ & $2,850 \pm 86.6^{a}$ & $4,330 \pm 991^{a}$ & $1,02 \pm 0.23^{a}$ & $1.52 \pm 0.35^{b}$ \\
\hline Average & $4,337 \pm 98.0$ & $2,703 \pm 77.9$ & $5,605 \pm 806$ & $1.29 \pm 0.18$ & $2.08 \pm 0.19$ \\
\hline
\end{tabular}

Note: Mean \pm Standard Error; Means followed by the same letter are not significantly different at 0.05 level as determined by Duncan

\subsection{Yields and nutrients in the soil}

Rice yields of $\mathrm{T} 1, \mathrm{~T} 2$ and $\mathrm{T} 3$ treatments were from 4.25 to 4.40 ton.ha ${ }^{-1}$ and there was no significant difference between three treatments ( $p>0,05)$ (Table 4). It needs at least two or even longer time to see the difference in yield among different rice straw management (Surekha et al. 2003; Son et al, 2008; Khuong and Hung, 2014; Du et al, 2014). Besides, the yield is better improved in Spring - Winter Season rather than in Autumn Winter season as in this experiment. The results in Fig. 7 and Fig. 8 show that organic carbon content and nitrogen available $\left(\mathrm{N}-\mathrm{NH}_{4}{ }^{+}\right.$and $\mathrm{N}-\mathrm{NO}_{3}{ }^{-}$) in the soil in treatment $\mathrm{T} 1$ was significantly higher than in T2 and T3 at the end of the season. Mil et al. (2012) reported that straw incorporation in soil returns $40 \%$ of $N$, $30 \%$ of $\mathrm{P}$ and $80 \%$ of $\mathrm{K}$ (which is absorbed by rice); straw incorporation also increases organic matter in soil as well. On the other hand straw burning results in losing $70-80 \%$ of $C$ and $N$ in straw (Hill et al., 1999). The improvement of carbon and nitrogen contents available in soil was one of the evidence that soil and paddy yield can be improved in the long term.

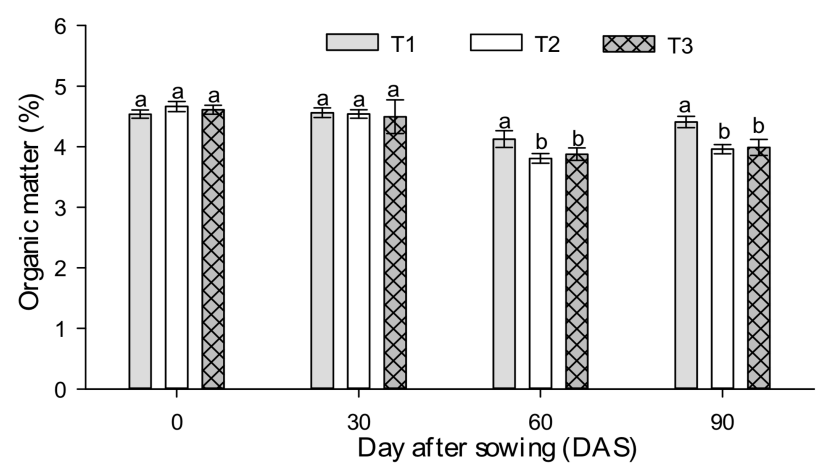

Figure 7. Organic matter in the soil (\%)

Note: Mean \pm Standard Error; Means followed by the same letter are not significantly different at 0.05 level as determined by Duncan 


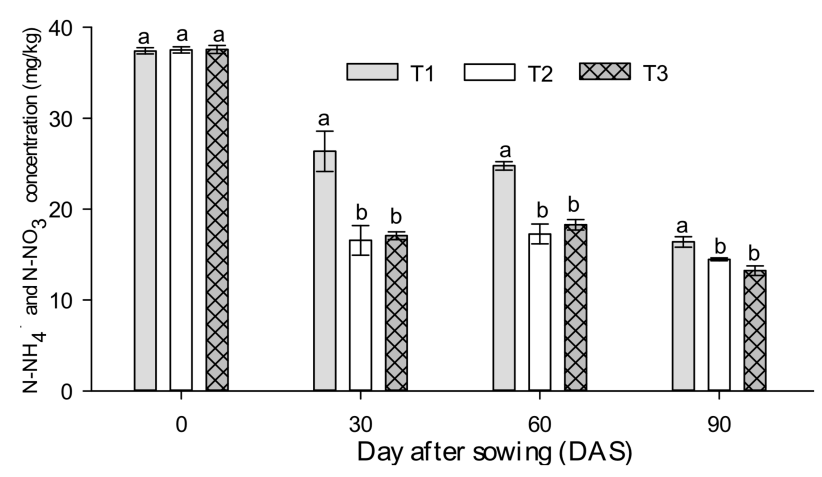

Figure 8. $\mathrm{N}-\mathrm{NH}_{4}{ }^{+}$and $\mathrm{N}-\mathrm{NO}_{3}{ }^{-}$concentration in soil

Note: Mean \pm Standard Error; Means followed by the same letter are not significantly different at 0.05 level as determined by Duncan

\subsection{Total greenhouse gas emissions (GHGE)}

Figure 9 shows GHGE ( $\mathrm{kg} \mathrm{CO}$ eq.ha ${ }^{-1}$ ) of the components constituting to the total emissions for three treatments (i.e. T1, T2, and T3). Total GHGE was in the range of 8,187$10,739 \mathrm{~kg} \mathrm{CO}_{2}$ eq ha ${ }^{-1}$, equaling to $1.93-2.46 \mathrm{~kg} \mathrm{CO}_{2}$-eq kg paddy produced (moisture content of paddy was at $14 \%$ in wet basis). The results showed that incorporation of all straw (T1) had the highest GHGE at 10,739 $\mathrm{kg} \mathrm{CO}_{2}$-eq ha ${ }^{-1}$ season $^{-1}$. Contribution to the overall GHGE, the highest was from direct field-emission during rice cultivation ranging $53-66 \%$ of the total GHGE. Mechanized operations consuming fuel also contributed a range of $26-34 \%$, while the agronomic inputs contribute about $7 \%$ of the total emissions.

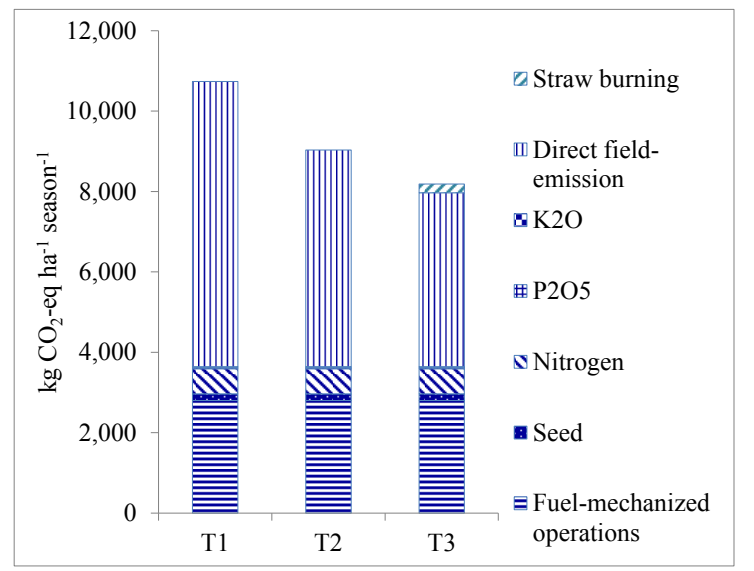

Figure 9. Total greenhouse gas emissions from three treatments

\section{Conclusions}

$\mathrm{CH}_{4}$ and $\mathrm{N}_{2} \mathrm{O}$ emission rates were not significantly different among the treatments; however, there were high variations of $\mathrm{N}_{2} \mathrm{O}$ emission after the dates when urea was applied. Direct field emissions of $\mathrm{CH}_{4}, \mathrm{~N}_{2} \mathrm{O}$ and $\mathrm{CO}_{2}$ equivalent $\left(\mathrm{CO}_{2 \text { eq }}\right)$ are not significantly different among the three treatments, but the amount of $\mathrm{CO}_{2 \text { eq }}$ per kg straw in $\mathrm{T} 1$ of incorporating rice straw treated Trichoderma is significantly higher than in T3 of in-field burning straw. LCA based analysis resulted in total GHGE in the range of 1.93-2.46 $\mathrm{kg} \mathrm{CO}_{2}$-eq $\mathrm{kg}^{-1}$ paddy produced consisting of $53-66 \%$ from direct soil emissions. Incorporation of straw treated with Trichoderma did not indicate the improvement of paddy yield. However, the organic matter and $\mathrm{N}-\mathrm{NH}_{4}{ }^{+}$and $\mathrm{N}-\mathrm{NO}_{3}{ }_{3}^{-}$of this treatment were higher than those from other researches. This research was just conducted in one crop season, however, the results have initial implications for the other crop seasons. To verify these results, we recommend to conduct further experiments with replications of crop seasons and extending to other seasons and cropping systems.

Acknowledgement. This research was conducted in collaboration with the International Rice Research Institute (IRRI) through the BMZ-IRRI project "Scalable straw management options for sustainability and low environmental footprint in rice-based production systems" (contract No. 81194994). We would like to thank Dr. Nguyen Thanh Nghi (NLU) for supporting this study. Thanks to all the students in CTU, especially Thi Quoc Phong, Vu Quoc Tin and Ho Minh Nhut, and the staff of DTARC for supporting the data collection in this study.

\section{References}

[1] Bharati, K., S.R. Mohanty, V.R. Rao and T.K. Adhya, 2001. Influence of flooded and non-flooded conditions on methane efflux from two soils planted to rice. Chemosphere Global Change Science, 3:25-32.

[2] Bhattacharyya, P., K.S. Roy, S. Neogi, T.K. Adhya, K.S. Rao and M.C. Manna, 2012. Effects of rice straw and nitrogen fertilization on greenhouse gas emissions and carbon storage in tropical flooded soil planted with rice. Soil and Tillage Research, 124: 119-130.

[3] Gadde, B., S. Bonnet, C. Menke and S. Garivait, 2009. Air pollutant emissions from rice straw open field burning in India, Thailand and the Philippines. Environmental Pollution, 157: 1554-1558.

[4] Gao, S., K. Tanji and S. C. Scadaci, 2003. Incorporating straw may induce sulfide toxicity in paddy rice. California Agriculture Journal, 57: 55-59.

[5] Hill, J.D, G.M. Brandon, S.M. Broader and A.U. Eke, 1999. Winter flooding and straw management: Implication for rice production. Agronomy progress report 1994-1996, 264: 5-25.

[6] Tin, H. Q., N.H. Cuc, N.V Sanh, N.V. Anh, J. Hughes, T.T Hoa and T. T. Ha, 2012. Low $\mathrm{CH}_{4}$ emission rice production in An Giang province - Dry season 2010-2011 (in Vietnamese). Scientific Journal of Can Tho University, 23a: 31-41.

[7] IPCC, 2006. 2006 IPCC guidelines for national greenhouse gas inventories. Volume 4 and 5 . Prepared by the National Greenhouse Gas Inventories Programme. Eggleaston, H.S., Buendia, L. Miwa, K. Ngara, T. and Tanabe, $\mathrm{K}$ (Eds).

[8] Jiang, J.Y. Y. Huang and L.G. Zong, 2003. Influence of water controlling and straw application on $\mathrm{CH}_{4}$ and $\mathrm{N}_{2} \mathrm{O}$ emissions from rice field. China Environmental 
Science, 23: 552-556.

[9] Linquist, B.A., M.A.A. Adviento-Borbe, C. Pittelkow, C. van Kessel and K.J. van Groenigen, 2012. Fertilizer management practices and greenhouse gas emissions from rice systems: a quantitative review analysis. Field Crops Res, 135: 10-21.

[10] Lou, Y., Ren, L., Li, Z., Zhang, T., Inubushi, K. 2007. Effect of rice residues on carbon dioxide and nitrous oxide emissions from a paddy soil of subtropical china. Water Air Soil Pollut, 178: 157-168.

[11] Trinh, M.V, T.V. The and B.T.P. Loan, 2013. Potential to mitigate $\mathrm{GHG}$ emissions from rice production in $\mathrm{Vi}$ etnam (in Vietnamese). http://www.iae.vn/. Accessed on 16/2/2017.

[12] Neue, H.U. and R.L. Sass, 1998. The Budget of Methane from Rice Fields. IGACtivities NewsLetter, 12: 311.

[13] Truc, N.T.T, 2011. Comparative assessment of using rice straw for rapid composting and straw mushroom production in mitigating greenhouse gas emissions in Mekong Delta, Vietnam and Central Luzon, Philippines. PhD dissertation. University of the Philippines Los Baños.

[14] Khuong, N. Q. and N.N. Hung, 2014. Effects of the rice straw compost incorporation on methane and nitrous oxide emissions and rice yield in the greenhouse condition (in Vietnamese). Scientific Journal of Can Tho University, 32: $46-52$.

[15] Hoi, N.T., 2008. Influences of fresh rice straw and stubble incorporation in flooded soils on rice growth in Mekong Delta (in Vietnamese). PhD dissertation. Can Tho University.

[16] Du, N.X., T.T Nga and N.T.K Phuoc, 2014. Rice straw treatment on the field using bio-productions in Spring - Summer crop at Cai Be District, Tien Giang Province (in Vietnamese). Scientific Journal of Can Tho University. Special Issue in Agriculture: 81 - 86.

[17] Parkin, T., A. Mosier, J. Smith, R. Venterea, J. Johnson, D. Reicosky, G. Doyle G. McCarty and J. Baker, 2003. Chamber-based Trace Gas Flux Measurement Protocol. USDAARS GRACEnet

[18] Pittelkow, C.M., M.A.A. Adviento-Borbe, C. van Kessel, J.E. Hill and B.A. Linquist, 2014. Optimizing rice yields while minimizing yield-scaled global warming potential. Glob. Chang. Biol, 20: 1382-1393.

[19] Romasanta, R.R., Sander, B.O., Gaihre, Y.K., Alberto, M.C., Gummert, M., Quilty,J., Nguyen, V.H., Castalone, A.G., Balingbing, C., Sandro, J., Correa,T., Wassmann, R., 2017. How does rice straw burning compare with other straw management practices in terms of on-field $\mathrm{CH}_{4}$ and $\mathrm{N}_{2} \mathrm{O}$ emissions? A comparative field experiment, Agriculture, Ecosystems and Environment. Agriculture, Ecosystems and Environment, 239:143-153.
[20] Snyder, C. S., T. W. Bruulsema and T.L. Jensen, 2007. Greenhouse gas emissions from cropping systems and the influence of fertilizer management-a literature review. International Plant Nutrition Institute, Norcross, Georgia, U.S.A.

[21] Surekha, K., A.P. P. Kumari, M. N. Reddy, K. Satyanarayana and P.C. Sta Cruz, 2003. Crop residue management to sustain soil fertility and irrigated rice yields. Nutrient Cycling in Agroecosystems. Volume 67, Number 2: 145-154.

[22] Mil, T.T, P. N. M. Trung and V.T. Guong, 2012. Effect of rice straw treated and organic amendment on soil fertility and rice yield in Chau Thanh district, Hau Giang province (in Vietnamese). Scientific Journal of Can Tho University, 22a: 253-260.

[23] Son, Tran Thi Ngoc, L.H. Man, C.N. Diep, T.T.A. Thu and N.N. Nam, 2008. Bioconversion of paddy straw and biofertilizer for sustainable rice based cropping systems. Omonrice 16 Journal, Cuu Long Rice Research Institute, Can Tho - Vietnam. pp 57-70.

[24] Tuyen, Tran Quang and P. S. Tan, 2001. Effects of straw management, tillage practices on soil fertility and grain yield of rice. Omonrice 9 Journal, Cuu Long Rice Research Institute, Can Tho - Vietnam. pp 74-78.

[25] Vietnam Second Communication (VSC), 2014. The initial updated report of Vietnam to the United Nations Framework Convention on Climate Change.Wassmann, R. Latin, R.S. and Neue, H.U (Eds), 2000. Methane emissions from rice field in Asia. III. Mitigation options and future search needs. Nutrient Cycling in Agroecosystems, 58: 23 - 36.

[26] Nam, T.S, N.T.H Nhu, N.H. Chiem, N.V.C. Ngan, L.H. Viet and Kjeld Ingvorsen, 2014. To quantify the seasonal rice straw and its use indifferent provinces in the Vietnamese Mekong Delta (in Vietnamese). Scientific Journal of Can Tho University, 32: 87 - 93.

[27] Truc, N.T.T, Z. M. Sumalde, F. G. Palis and R. Wassmann, 2013. Farmers' Awareness and Factors Affecting Farmers' Acceptance to Grow Straw Mushroom in Mekong Delta, Vietnam and Central Luzon, Philippines. International Journal of Environment and Rural Development. Volume 4. Number 2. P.179-184.

[28] Truc. N.T.T, Z. M. Sumalde, M. V. O. Espaldon, E. P. Pacardo, C. L. Rapera and F. G. Palis, 2012. Farmers' Awareness and Factors Affecting Adoption of Rapid Composting in Mekong Delta, Vietnam and Central Luzon, Philippines. Journal of Environmental Science and Management 15(2):59-73.

[29] Minamikawa, K., T. Tokida, S. Sudo, A. Padre and K. Yagi, 2015. Guidelines for Measuring $\mathrm{CH}_{4}$ and $\mathrm{N}_{2} \mathrm{O}$ Emissions from Rice Paddies by a Manually Operated Closed Chamber Method. National Institute for AgroEnvironmental Sciences, Tsukuba, Japan. 